\title{
Nomenclatural and taxonomic review of Passifloraceae species illustrated and described by Vellozo in Flora Fluminensis
}

\author{
Armando Carlos Cervi ${ }^{1,2}$ and William Antonio Rodrigues ${ }^{1}$
}

Recebido em 17/05/2010. Aceito em 5/11/2010

\begin{abstract}
RESUMO - (Revisão nomenclatória e taxonômica das espécies de Passifloraceae descritas e ilustradas por Vellozo na Flora Fluminensis) A nomenclatura e a taxonomia das 25 espécies de Passifloraceae nomeadas por Vellozo na Flora Fluminensis foram revisadas com base na consulta das estampas e diagnoses latinas. Passiflora mediterranea, P. ovalis, P. porophylla, P. silvestris, P. tetraden e P. villosa são as espécies propostas por Vellozo aceitas aqui. Quinze espécies (P. arvensis, P. bilobata, P. dentata, P. diaden, P. globosa, P. lunata, P. maliformis, P. oliviformis, P. pallida, P. pertusa, P. polyaden, $P$. quadrangularis, $P$. rubra, $P$. sururuca e $P$. violacea) são sinônimas, foram identificadas erroneamente ou possuem nomes ilegítimos: Passiflora edulis, $P$. foetida e $P$. racemosa foram corretamente identificadas; no entanto, a planta reconhecida por Vellozo como $P$. foetida é atualmente considerada $P$. foetida var. fluminensis. Passiflora obtusa foi considerada incertae sedis.
\end{abstract}

Palavras-chave: Brasil, Passiflora, José Mariano da Conceição Vellozo, nomenclatura, taxonomia

ABSTRACT - (Nomenclatural and taxonomic review of Passifloraceae species described and illustrated by Vellozo in Flora Fluminensis). The nomenclature and taxonomy of the 25 species of Passifloraceae named by Vellozo in Flora Fluminensis were reviewed by examining the plates and Latin diagnoses. Passiflora mediterranea, P. ovalis, P. porophylla, P. silvestris, P. tetraden, and $P$. villosa are species proposed by Vellozo that are accepted herein. Fifteen species (P. arvensis, P. bilobata, P. dentata, P. diaden, P. globosa, P. lunata, P. maliformis, P. oliviformis, P. pallida, P. pertusa, P. polyaden, P. quadrangularis, P. rubra, P. sururuca, and $P$. violacea) are synonyms, were misidentified, or have illegitimate names. Passiflora edulis, P. foetida, and $P$. racemosa were correctly identified; however, the plant recognized by Vellozo as $P$. foetida is now considered P. foetida var. fluminensis. Passiflora obtusa was considered incertae sedis.

Key words: Brazil, Passiflora, José Mariano da Conceição Vellozo, nomenclature, taxonomy

Flora Fluminensis is the first and one of the most important works edited by a Brazilian on the flora of Brazil. It is the result of the first botanical expedition in southern Brazil, which was lead by a Franciscan friar, José Mariano da Conceição Vellozo (1742-1811). The goal of the expedition was to gather information on natural resources, especially the flora, from the captainship of Rio de Janeiro to the hinterland of the captainship of São Paulo. The research took place between 1782 and 1790 and the published work included 1,640 species and 374 genera, 104 of which were considered new. Vellozo was supported by the Vice-Roy Luis de Vasconcellos e Souza and was helped by a number of collaborators, including several draftsmen, the military (during the fieldwork), and other botanists who described and identified the plants and probably came from Portugal where he took the entire collection to finish the project (Damasceno 1977; Lima 1995).

Vellozo (1831) illustrated 25 species of Passiflora, but the descriptions were published later (Vellozo 1881), with the exception of P. racemosa. Flora Fluminensis was published in three distinct periods: some text was printed in 1825, excluding the species of Passifloraceae, but effectively published in 1829 (from September $7^{\text {th }}$ to November $28^{\text {th }}$ ); the illustrations were printed in 11 volumes, which were edited in 1827 and effectively published in 1831 (on October 29 $9^{\text {th }}$ ); and the nearly complete text, with all species described, was issued on July $8^{\text {th }}, 1881$ (Borgmeier 1937; the reasons for the delays in the publications are discussed in Carauta 1973 and Lima 1995).

Binomials that were not new taxa were included in the Flora Fluminensis along with their botanical descriptions, indigenous names, uses and habitats, but without authorship. By examining the list of names, the diagnoses and the illustrations in volume 9 (Vellozo, 1831), we noticed that some binomials used by Vellozo were synonyms or homonyms of names previously adopted by others. In spite of this, Flora Fluminensis is a remarkable work that has been consulted and reviewed by numerous taxonomists worldwide. Unfortunately, the botanical collections made by Vellozo were expropriated during the Napoleonic invasion of Portugal, in 1808, and disappeared after they were taken to France. Due to the lack of voucher collections, the plates, many of them of excellent quality, are usually the best option that botanists have for reviewing the described taxa (e.g., Sampaio \& Peckolt 1943; Stellfeld 1950; Mello Filho 1975; Lima 1995).

The 25 species of Passifloraceae named by Vellozo in Flora Fluminensis are listed below; the accepted names are in boldface. The analysis was based on the plates and Latin diagnoses in Vellozo's $(1831,1881)$ works and the names have been reviewed and updated to reflect current nomenclatural and taxonomic perspectives. 
1- Passiflora arvensis Vell., Fl. Flumin. Icon. 9: tab. 71. 1831 ('1827'); Arch. Mus. Nac. Rio de Janeiro 5: 376. 1881. = P. ovalis Vell. [Vitta \& Bernacci 2004; contra Killip 1938, who identified it as Tetrastylis ovalis (Vell.) Killip].

2- Passiflora bilobata auct. non Juss. (1805) in Vell., Fl. Flumin. Icon. 9: tab. 78. 1831 ('1827'); Arch. Mus. Nac. Rio de Janeiro 5: 378. 1881. = P. rubra L. (Killip 1938; contra Sampaio \& Peckolt 1943, who identified it as $P$. capsularis L.).

3- Passiflora dentata Vell., Fl. Flumin. Icon. 9: tab. 94.1831 ('1827'); Arch. Mus. Nac. Rio de Janeiro 5: 381. 1881.= P. kermesina Link \& Otto (Killip 1938; Cervi 1997). It is not $P$. raddiana DC.; contra Sampaio \& Peckolt 1943).

4- Passiflora diaden Vell., Fl. Flumin. Icon. 9: tab. 90. 1831 ('1827'); Arch. Mus. Nac. Rio de Janeiro 5: 380. 1881. =P. edulis Sims (Killip 1938; Cervi 1997).

5- Passiflora edulis Sims (1818) in Vell., Fl. Flumin. Icon. 9: tab. 89.1831 ('1827’); Arch. Mus. Nac. Rio de Janeiro 5: 380.1881.

6- Passiflora foetida auct. non L. (1753) in Vell., Fl. Flumin. Icon. 9: tab. 86. 1831 ('1827'); Arch. Mus. Nac. Rio de Janeiro 5: 379. 1881. $=$ P. foetida var. fluminensis (M. Roem) Killip (Killip 1938; contra Gardner 1845 and Sampaio \& Peckolt 1943, who identified it as P. vellozii Gardner).

7- Passiflora globosa Vell., Fl. Flumin. Icon. 9: tab. 85. 1831 ('1827'); Arch. Mus. Nac. Rio de Janeiro 5: 379. 1881. = P. suberosa L. (Killip 1938; Sampaio \& Peckolt 1943).

8- Passiflora lunata auct. non Sm. (1790); Fl. Flumin. Icon. 9: tab. 80. 1831 ('1827'); Arch. Mus. Nac. Rio de Janeiro 5: 378. 1881. = P. rubra L. (Killip 1938; contra Sampaio \& Peckolt 1943, who identified it as $P$. capsularis L.).

9- Passiflora maliformis auct. non L. (1753) in Vell., Fl. Flumin. Icon. 9: tab. 73.1831 ('1827'); Arch. Mus. Nac. Rio de Janeiro 5: 376. 1881. = P. alata Curtis (Killip 1938, as $P$. alata 'Dryand.').

10- Passiflora mediterranea Vell., Fl. Flumin. Icon. 9: tab. 72. 1831 ('1827'); Arch. Mus. Nac. Rio de Janeiro 5: 376. 1881.

Passiflora jilekii Wawra, Oesterr. Bot. Z. 13: 110. 1863. (as 'Jileki'). Syn. nov.

11- Passiflora obtusa auct. non L. (1753) in Vell., Fl. Flumin. Icon. 9: tab. 81. 1831 ('1827'); Arch. Mus. Nac. Rio de Janeiro 5: 378. 1881. Incertae sedis.

It is not P. pohlii Mast. (contra Killip 1938) because, based on the plate, it appears to be glabrous. It cannot be safely considered a synonym of $P$. organensis Gardner (Gardner 1845, Sampaio \& Peckolt 1943) because the flower was not illustrated.

12- Passiflora oliviformis auct non Mill. (1768) in Vell., Fl. Flumin. Icon. 9: tab. 83. 1831 ('1827'); Arch. Mus. Nac. Rio de Janeiro 5: 379. 1881. (as 'olivaeforma'). = P. suberosa L. (Killip 1938; Sampaio \& Peckolt 1943).

13- Passiflora ovalis Vell., Fl. Flumin. Icon. 9: tab. 75.1831 ('1827'); Arch. Mus. Nac. Rio de Janeiro 5: 377. 1881.

14- Passiflora pallida auct. non L. (1753); Vell., Fl. Flumin. Icon. 9: tab.70. 1831 ('1827'); Arch. Mus. Nac. Rio de Janeiro 5: 376. 1881. = P. mucronata Lam. (Killip 1938; Sampaio \& Peckolt 1943; Cervi 1997).

15- Passiflora pertusa Vell., Fl. Flumin. Icon. 9: tab. 79. 1831 ('1827'); Arch. Mus. Nac. Rio de Janeiro 5: 378. 1881. = P. porophylla Vell. Syn. nov. (contra Killip 1938 and Sampaio \& Peckolt 1943, who identified it as P. organensis Gardner).

16- Passiflora polyadena Vell., Fl. Flumin. Icon. 9: tab. 92 1831 ('1827'). (as 'polyaden'); Arch. Mus. Nac. Rio de Janeiro 5: 381. 1881. = P. foetida L. var. foetida (Killip 1938; Sampaio \& Peckolt 1943).

17- Passiflora porophylla Vell., Fl. Flumin. Icon. 9: tab. 82. 1831 ('1827'); Arch. Mus. Nac. Rio de Janeiro 5: 378. 1881 .

Passiflora organensis Gardner, London J. Bot. 4: 104. 1845. Syn. nov.

18- Passiflora quadrangularis auct. non L. (1759) in Vell., Fl. Flumin. Icon. 9: tab. 76. 1831 ('1827'); Arch. Mus. Nac. Rio de Janeiro 5: 377. 1881. = P. alata Curtis.

It differs from $P$. quadrangularis $\mathrm{L}$. because the leaves have 6 or 9 pairs of veins rather than 10-12 pairs on each side (contra Sampaio \& Peckolt 1943).

19- Passiflora racemosa Brot. (1818) in Vell., Fl. Flumin. Icon. 9: tab. 93. 1831 ('1827').

It was not published as a new species (contra Sampaio \& Peckolt 1943).

20- Passiflora rubra Vell., Fl. Flumin. Icon. 9: tab.77. 1831 ('1827'); Arch. Mus. Nac. Rio de Janeiro 5: 377. 1881, hom. post., non L. (1753). = Passiflora porophylla Vell. Syn. nov. (contra Gardner 1845, Killip 1938, Sampaio \& Peckolt 1943, who identified it as P. organensis Gardner).

21- Passiflora silvestris Vell., Fl. Flumin. Icon. 9: tab. 74. 1831 ('1827'); Arch. Mus. Nac. Rio de Janeiro 5: 377. 1881 . 
Passiflora galbana Mast., Gard. Chron. 20: 555; fig. 97. 1896. Syn. nov.

22- Passiflora sururuca Vell., Fl. Flumin. Icon. 9: tab. 88 1831 (1827); Arch. Mus. Nac. Rio de Janeiro 5: 380 1881. = P. setacea DC. (Killip 1938; Sampaio \& Peckolt 1943; Cervi 1997).

23- Passiflora tetraden Vell., Fl. Flumin. Icon. 9: tab. 91. 1831 ('1827’); Arch. Mus. Nac. Rio de Janeiro 5: 381. 1881.

Passiflora sidifolia M. Roem., Fam. Nat. Syn. Monogr. 2: 173. 1846 (as 'sidaefolia'). Syn. nov.

24- Passiflora villosa Vell., Fl. Flumin. Icon. 9: tab. 87. 1831 ('1827'); Arch. Mus. Nac. Rio de Janeiro 5: 380. 1881.

25- Passiflora violacea Vell., Fl. Flumin. Icon. 9: tab. 84. 1831 ('1827'); Arch. Mus. Nac. Rio de Janeiro 5: 379. 1881. = P. amethystina J.C. Mikan (Deginani 2001)

\section{Acknowledgments}

This research was funded by a PQ grant $(\mathrm{CNPq})$ that was awarded to both authors.

\section{References}

Borgmeier, T. 1937. A história da "Flora Fluminensis" de Frei Velloso. Rodriguésia 9: 77-96.

Carauta, J.P.P. 1973. The text of Vellozo's Flora Fluminensis and the effective date of publication. Taxon 22(2-3): 281-284.

Cervi, A.C. 1997. Passifloraceae do Brasil. Estudo do gênero Passiflora L., subgênero Passiflora. Fontqueria 45: 1-92.

Deginani, N.B. 2001. Las especies argentinas del género Passiflora (Passifloraceae). Darwiniana 39(1-2): 43-129.

Damasceno, D. 1977. Introdução. In: Veloso, J.M.C. Plantas fluminenses descritas por frei Veloso. Anais da Biblioteca Nacional 96: 123-133.

Gardner. G. 1845. Passiflora vellozii. London Journal of Botany 4: 103.

Killip, E.P. 1938. The American species of Passifloraceae. Field Museum of Natural History. Botanical Series 19(1-2): 1-613.

Lima, H.C. 1995. Leguminosas da Flora Fluminensis - J.M.C. Vellozo - Lista atualizada das espécies arbóreas. Acta Botanica Brasilica 9(1): 123-146.

Mello Filho, L.E. 1975. O gênero Heliconia na Flora Fluminensis de Frei José Mariano da Conceição Vellozo. Revista Brasileira de Biologia 35(2): 331-337.

Sampaio, A.J. \& Peckolt, O. 1943. A nomenclatura das espécies na "Flora Fluminensis" de Conceição Veloso e sua correspondência atual. Arquivos do Museu Nacional 23: 333-394.

Stellfeld, C. 1950. As aráceas da "Flora Fluminensis". Arquivos do Museu Paranaense de Curitiba 8(4): 165-188.

Vellozo, J.M.C. 1831 (1927). Passiflora. Tab. 70-94. In: Florae fluminensis icones vol.9. Parisiis, ex off. lithogr. Senefelder.

Vellozo, J.M.C. 1881. Passiflora. In: Flora Fluminensis. Archivos do Museu Nacional do Rio de Janeiro 5: 376-381.

Vitta, F.A. \& Bernacci, L.C. 2004. A new species of Passiflora in section Tetrastylis (Passifloraceae) and two overlooked species of Passiflora from Brazil. Brittonia 56(1): 89-95. 